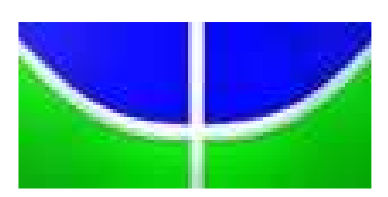

Universidade de Brasília

Centro de Excelência em Turismo

Pós-graduação Lato Sensu

Curso de Especialização em Gestão de Negócios em Turismo

ESTUDO DAS METODOLOGIAS PARA PLANO DE DESENVOLVIMENTO TURÍSTICO

ANA CAROLINA DOS SANTOS CARVALHO

Elisangela Aparecida Machado da Silva

Prof. Orientadora 


\author{
Universidade de Brasília \\ Centro de Excelência em Turismo \\ Pós-graduação Lato Sensu \\ Curso de Especialização em Gestão de Negócios em Turismo
}

\title{
ESTUDO DAS METODOLOGIAS PARA PLANO DE DESENVOLVIMENTO TURÍSTICO
}

\section{ANA CAROLINA DOS SANTOS CARVALHO}

Elisangela Aparecida Machado da Silva, Mestre

Prof. Orientadora

Monografia apresentada ao Centro de Excelência em Turismo - CET, da Universidade de Brasília - UNB, em cumprimento às exigências acadêmicas parciais do curso de pós-graduação lato sensu em Gestão de Negócios em Turismo para a obtenção do grau de Especialista. 
CARVALHO, Ana Carolina dos Santos.

Estudo das Metodologias para plano de desenvolvimento turístico / Ana Carolina dos Santos Carvalho - Brasília, 2007.

Monografia (especialização) - Pós Graduação em Gestão de Negócios em Turismo, 2007. Universidade de Brasília - UnB

Orientadora: Elisangela Aparecida Machado da Silva

1. Turismo 2. Metodologia 3. Plano de desenvolvimento 


\title{
Universidade de Brasília \\ Centro de Excelência em Turismo
}

Pós-graduação Lato Sensu

Curso de Especialização em Gestão de Negócios em Turismo

\section{ESTUDO DAS METODOLOGIAS PARA PLANO DE DESENVOLVIMENTO TURÍSTICO}

\author{
ANA CAROLINA DOS SANTOS CARVALHO \\ Elisangela Aparecida Machado da Silva, Msc. \\ Professor Orientador \\ Rogério Ferreira de Souza Dias, Esp. \\ Professor Avaliador \\ Shirley Pontes, Msc. \\ Professor Avaliador
}

Monografia apresentada ao Centro de Excelência em Turismo - CET, da Universidade de Brasília - UNB, em cumprimento às exigências acadêmicas parciais do curso de pós-graduação lato sensu em Gestão de Negócios em Turismo para a obtenção do grau de Especialista. 
DEDICATÓRIA

Aos meus pais, irmãos e amigos que estão sempre me apoiando. 


\section{AGRADECIMENTOS}

Aos professores, colegas e amigos que me apoiaram nesta caminhada. 


\section{LISTA DE TABELAS}

Tabela1: Características do Planejamento.................................................29 


\section{LISTA DE FIGURAS}

Figura1: Elaboração positiva de um plano. 


\section{RESUMO}

O turismo é uma atividade antiga que passou a ser estudada mais recentemente como ciências humanas, sendo assim, possui poucos estudos científicos e metodológicos. Neste trabalho são estudadas algumas metodologias mais recentes para a elaboração de planos de desenvolvimento do turismo. Traz um entendimento do que é metodologia, planejamento e plano, planejamento turístico e plano de desenvolvimento abordando alguns dos conceitos de autores brasileiros renomados do turismo. A atividade turística se diferencia bastante entre uma localidade e outra, fazendo com que o planejamento seja especifico e mais efetivo para cada destino. Isto acontece porque cada localidade possui características econômicas, sociais, culturais e ambientais diferenciadas. Com o planejamento estas diferenças ficarão em evidência, apresentando aos turistas a potencialidade dos atrativos locais e visando promover melhorias econômica, social e ambiental para o local envolvido com o desenvolvimento adequado da atividade turística. Após o estudo dos pressupostos teóricos vamos analisar as principais características metodológicas dos planos de desenvolvimento do turismo. Portanto, serão estudados dois planos de desenvolvimento turístico de destinos diferentes para que se possa perceber as diferentes metodologias utilizadas na elaboração dos planos sob três enfoques: visão sistêmica, visão municipal e visão sustentável.
1. Turismo
2. Planejamento
3. Plano de desenvolvimento 


\begin{abstract}
Tourism is an antique activity that started to be studied recently as human science, that is the reason that there are not many scientific and methodological studies. This text presents the study of some recently methodologies to build tourism developing plans. Helps to understand methodology, planning and plan, tourism planning $e$ developing plan about some concepts studied by researchers. The tourism activity is so different in each local and that is why the planning has to be specific to be more effective to each destiny. This happens because each local has different economic, social, cultural and environmental characteristics. With the planning this differences will become evident and allow tourists to see all potential of local attractions. This approach will bring economic, social and environmental improvement to the area. After theoretical studies, the main methodological characteristics applied in two development tourism projects from two different locales will be analyzed. The result of that analysis will be compared through three different point of view: systemic, municipal and sustainable approach.
\end{abstract}
1. Tourism
2. Planning
3. Development plan 


\section{SUMÁRIO}

1 INTRODUÇÃO

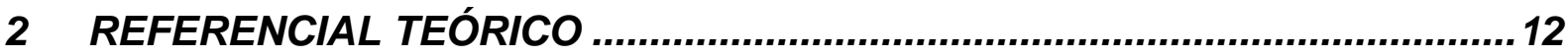

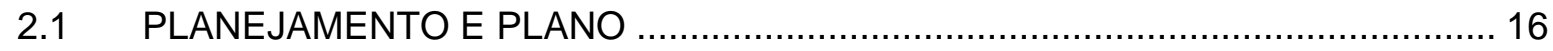

2.2 EVOLUÇÃO DOS ESTUDOS EM PLANEJAMENTO DO TURISMO..................... 20

2.3 PLANEJAMENTO EM TURISMO E PLANOS DE DESENVOLVIMENTO ............ 25

3 ESTUDO DOS PLANOS DE DESENVOLVIMENTO INTEGRADO DO TURISMO SUSTENTÁVEL DO PÓLO VALE DO JEQUITINHONHA E DA ÁREA

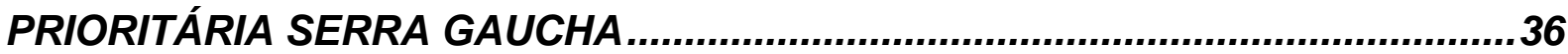

3.1 DESCRIÇÕES DOS PLANOS DE DESENVOLVIMENTO DO TURISMO ……..... 36 3.1.1 Plano de desenvolvimento integrado do turismo sustentável: Pólo Vale do Jequitinhonha 3.1.2 Plano de desenvolvimento integrado do turismo sustentável: Área Prioritária Serra Gaúcha41

3.2 VISÕES MUNICIPAL, SISTÊMICA E SUSTENTÁVEL ……............................ 44

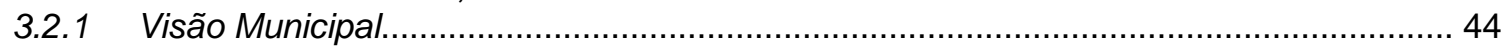

3.2.2 Visão Sistêmica …………………………………………………………….... 46

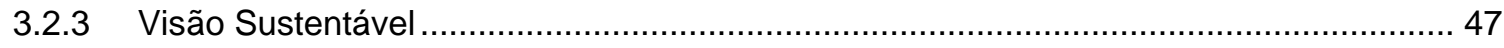

4 CONSIDERAÇÕES FINAIS

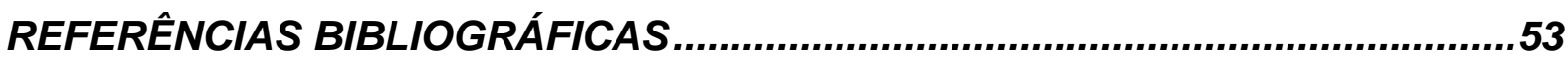




\section{INTRODUÇÃO}

O turismo vem conquistando espaço como campo de estudo em diversas áreas, porém há muito que ser feito no sentido de produzir conhecimento para que se possa revelar as dimensões deste fenômeno que vem crescendo e se tornando cada vez mais importante para o mundo.

Quando se estuda o fenômeno do turismo percebe-se a importância de se preservar e conservar produtos turísticos, que podem ser um monumento, um local ou mesmo uma cidade inteira, pois uma localidade pode se desenvolver economicamente utilizando-se de seu potencial turístico.

No turismo ocorrem transformações desenfreadas, como por exemplo, uma localidade passa a ser conhecida por ter sido cenário de uma novela ou notícia de jornal passando a ser, repentinamente, uma grande atração, normalmente por um curto período de tempo. Isto demonstra a falta de planejamento em turismo. Essa falta de planejamento acaba causando um impacto negativo à localidade, à comunidade e ao meio ambiente, podendo ser "lucrativo" durante o período de alta visitação, mas quando este período de "atração" passa, a comunidade percebe o estrago que foi feito à localidade.

No presente trabalho serão apresentados os principais pressupostos de metodologias utilizadas para planos de desenvolvimento do turismo, com destaque para a importância de se planejar o turismo, para que este se desenvolva de maneira a minimizar os impactos negativos causados à localidade e à sua 
população. Para que a comunidade esteja preparada para lidar com as transformações que o turismo possa trazer, garantindo, a partir destes estudos, a sobrevivência da atividade turística. Esta pesquisa mostra à comunidade que o turismo possui pontos positivos e pontos negativos, mas que quando planejado pode minimizar os efeitos negativos.

O objetivo deste trabalho é estudar as metodologias existentes para planos de desenvolvimento do turismo. Para isso, serão conceituados turismo e planejamento, contextualizada a evolução dos estudos de planejamento do turismo, estudado planejamento em turismo e desenvolvimento turístico. Para tal, foram definidos os objetivos específicos abaixo:

- $\quad$ Conceituar planejamento e plano;

- $\quad$ Contextualizar a evolução dos estudos de planejamento do turismo;

- Estudar planejamento em turismo e desenvolvimento turístico;

- Estudar metodologias para elaboração de planos de desenvolvimento turístico.

Foram estudadas as metodologias do "Plano de Desenvolvimento Integrado do Turismo Sustentável: Pólo Vale do Jequitinhonha" e do "Plano de Desenvolvimento Integrado do Turismo Sustentável: Área Prioritária Serra Gaúcha”. Este trabalho irá analisar as principais características metodológicas dos Planos de Desenvolvimento Turísticos que foram selecionados.

Um fator decisivo para a melhor efetivação do turismo em uma localidade é a implementação de um plano de desenvolvimento especifico. "A utilização do ciclo de vida de um produto, como instrumento do planejamento turístico, se justifica na 
localidade em estudo e nas medidas cabíveis para direcionar seu desenvolvimento" (Ruschmann, 1997: 103).

Este trabalho consiste em uma pesquisa na área de turismo, campo em que a pesquisa é bastante recente, tornando importantes as metodologias que conduzem um processo investigativo que preze a cientificidade dos resultados, se fazendo necessário o aprofundamento das pesquisas teóricas e metodológicas (Anjos, 2004: 22).

As questões teórico-metodológicas pautam-se, principalmente, no pressuposto de uma pesquisa interpretativa no sentido de tentar entender a importância das relações entre o plano de desenvolvimento, o destino turístico, os habitantes locais e órgãos do governo.

Utilizou-se o instrumento de coleta de dados que ocorreu de Dezembro de 2006 a Fevereiro de 2007, foram feitas pesquisas em fontes documentais e bibliográficas. A pesquisa documental abrangeu diversos livros, artigos, dissertações e teses sobre metodologia cientifica e da pesquisa, metodologias especificas para turismo, plano e planejamento, planejamento turístico, desenvolvimento do turismo e plano de desenvolvimento turístico.

A produção dos textos sobre os assuntos já expostos anteriormente teve inicio em Fevereiro de 2007, abordando diversos autores com o objetivo de analisar as metodologias que podem ser utilizadas para a elaboração de um plano de desenvolvimento da comunidade local no planejamento e na implementação.

Foram selecionados dois planos de desenvolvimento:

- Plano de desenvolvimento integrado do turismo sustentável: Pólo Vale do Jequitinhonha 
- Plano de desenvolvimento integrado do turismo sustentável: Área Prioritária Serra Gaúcha

O critério de seleção utilizado para a escolha dos planos foi:

- Estados diferentes;

- Enfoques a diferentes tipos de atrativos;

- Fácil acesso.

Os planos serão descritos para que se perceba o que estes têm em comum e serão analisados por três autores que dão enfoques diferentes ao planejamento, que são as visões seguintes: sistêmica, municipal e sustentável. E dentro destas perspectivas serão analisados três itens para que se possa perceber as diferenças dos enfoques que cada autor aborda, estes são:

- Estrutura para plano de desenvolvimento

- Características mais importantes para o planejamento

- Aspectos de turismo sustentável

Portanto, no primeiro momento será apresentado o referencial teórico com a conceituação de metodologia, de planejamento e plano, planejamento turístico e plano de desenvolvimento turístico. Em seguida será feito um breve histórico da evolução do planejamento, será apresentada a metodologia utilizada para a elaboração do trabalho. E serão apresentadas as analises das metodologias para plano de desenvolvimento turístico, buscando melhorar e desenvolver os destinos turísticos que necessitam do turismo para sobreviver. 


\section{REFERENCIAL TEÓRICO}

Inicialmente, se faz necessário conceituar metodologia para que se possa entender as metodologias de planos de desenvolvimento do turismo a serem estudadas aqui.

O estudo da metodologia permite analisar os fluxos turísticos para saber o número de turistas que entraram ou saíram de determinado destino em determinada época do ano, o perfil de cada turista com a identificação de suas necessidades e desejos, conhecer o mercado, os concorrentes, os serviços oferecidos aos turistas. Estas informações são necessárias quando se estuda o turismo, para satisfazer os clientes, adequar as ofertas turísticas de cada destinação de acordo com seus produtos turísticos e demanda.

Para Dencker (1998: 18) "a disciplina de metodologia cientifica estuda os métodos e processos utilizados para a obtenção e o desenvolvimento do conhecimento cientifico". Segundo ela, a principal característica da ciência é "...a reflexão e a construção de um corpo metodologicamente ordenado de conhecimento" (1998: 23).

As pessoas, para se relacionarem umas com as outras, possuem conhecimentos e habilidades que são transmitidas de uma para outra respeitando as diferenças e peculiaridades de cada cultura. Porém este conhecimento não é científico e sim "vulgar", ou seja, superficial. Este conhecimento se distingue do 
conhecimento cientifico por três características básicas, segundo Pizam (apud Schluter, 2003: 24):

"- Objetivo porque é independente da opinião pessoal do pesquisador a respeito do tema que estuda.

- Reproduzível porque é um processo que permite que outros pesquisadores cheguem ao mesmo resultado.

- É sistemático porque trata de conhecimentos organizados logicamente, utilizando procedimentos técnicos. E a sistematização organiza 0 processo de pesquisa em passos seqüenciais $e$ interdependentes, que devem ser específicos e planejados com antecipação".

Para o estudo de determinado assunto é imprescindível a identificação de métodos (estratégia-forma de proceder) e processos (aplicação) para que as informações obtidas sejam devidamente utilizadas e organizadas, gerando conhecimento.

No turismo, este conhecimento é adquirido através da realidade e do momento histórico em que está inserido. Assim como, o pesquisador que possui valores, ideologias, cultura, etc está inserido na realidade. Para que estes fatores não interfiram na pesquisa cientifica, são utilizados métodos para que haja norma a ser seguida durante a pesquisa.

Para Oracy Nogueira (apud Dencker, 1998: 19), método científico é "a sucessão de passos pelos quais se descobrem novas relações entre fenômenos que interessam a um determinado ramo cientifico ou aspectos ainda não revelados de um determinado fenômeno".

Segundo Dann (apud Schluter, 2003: 25), "método em ciências sociais significa a aceitação e avaliação de procedimentos estandardizados de acordo com a investigação que realiza”.

Para Schluter (2003: 25), "todo método precisa de uma teoria, isto é de um corpo de preposição logicamente interconectado que permita uma visão do fenômeno". 
E para Dencker (1998: 23), "o método cientifico é um conjunto de regras ou critérios que servem de referência no processo de busca de explicação ou da elaboração de previsão em relação a questões ou problemas específicos".

Para se estudar o turismo faz-se previsões ou prognósticos que avaliam os impactos futuros e as influências de cada decisão tomada. Assim, as técnicas que melhor se adaptam à previsão em turismo são, segundo Moeller e Shafer, citado por Schluter (2003: 32):

"- Exploração de tendências: baseia-se na suposição de que o futuro será uma extensão lógica do passado. Consiste na superação de experiências ou tendências do passado;

-Construção de cenários: consiste em relacionar diferentes eventos para formar o contexto de futuro. Uma forma de construir um cenário procurar respostas à pergunta: Que aconteceria se...?;

- Modelos analíticos: seu desenvolvimento foi muito influenciado pela informática e se baseia nas relações matemáticas entre elementos que se acredita que produzem ou influenciam o processo em questão;

- Opinião de especialistas: pede-se a pessoas que dominam o assunto que mencionem possíveis conseqüências de determinadas linhas de ação. Geralmente formam-se grupos de discussão em que os participantes aceitam/ refutam as opiniões colocadas;

- Técnica Delphi: é uma das mais populares em turismo. Baseia-se na suposição de que ainda que o futuro seja incerto, é possível fazer uma projeção de suas principais características com base na opinião de pessoas qualificadas".

O prognóstico é necessário para toda empresa, tanto do setor público como para o privado, de curto ou médio prazo para, por exemplo, implementar suas estratégias. E também a previsão a longo prazo pode, por exemplo, adequar a infraestrutura do destino para a demanda existente, estimar investimentos, etc.

Há três elementos que, segundo Dencker (1998: 23), formam a base da investigação científica e caracterizam o conhecimento como ciência: a teoria, o método e a técnica.

"- Uma técnica para registrar e quantificar os dados observados (dados do comportamento turístico), ordená-los e classificá-los

- Uma teoria que permita interpretar os dados, dotando-os de significação, ou, na falta desta, uma hipótese sobre o sentido da 
ação para se chegar á elaboração da teoria, baseada em leis cientificas, e

- Método cientifico".

Como em todas as ciências, no turismo também é importante utilizar metodologias para estudá-lo, utilizando-as como ferramentas para orientar ações empresariais e em planejamentos. Podem ser utilizados dois tipos de metodologia em turismo, segundo Dencker (1998: 34):

"- Metodologia quantitativa: Justifica suas afirmações através de números e equações.

- Metodologia qualitativa: Afirmações feitas mediante analise das influencias da sociedade, cultura, etc."

A metodologia quantitativa é essencial para apontar numericamente o que acontece no turismo. A metodologia qualitativa é de igual importância pois é possível perceber que as pessoas não são facilmente interpretáveis e agem de acordo com valores e crenças de sua sociedade, não podendo ser facilmente colocados em números.

Em atividades ligadas ao planejamento turístico, a utilização de técnicas e métodos científicos possuem os seguintes objetivos (Bissoli, 1998:35):

“- criação, elaboração, análise e interpretação de planos e projetos turísticos.

- Realização de estudos tendentes a explicar os fenômenos turísticos, bem como as respectivas origens, mudanças e evoluções.

- Análise dos efeitos dos pólos emissores e receptores sobre os indivíduos, grupos ou categorias sociais.

- Interpretação de dados sobre os costumes, práticas e hábitos de fluxos turísticos.

- Elaboração de projetos ou estudos de planejamento, organização, funcionamento e exploração de empreendimentos turísticos em empresas privadas ou públicas".

O turismo utiliza-se dos métodos e conceitos da maioria das ciências sociais consolidadas, aparecendo como objeto de estudos no ambiente de varias 
disciplinas, tornando difícil a delimitação do "campo de investigação" e prejudicando a formação de teorias específicas para torná-la uma disciplina única.

Entretanto, a multidisciplinaridade é a principal característica do turismo. Segundo a Organização Mundial do Turismo (OMT), existem dois problemas que dificultam o desenvolvimento do conhecimento turístico em função da multidisciplinaridade, que são:

"- os investigadores trabalham apenas dentro dos limites de suas disciplinas;

- a investigação é parcelada e atomizada".

Entretanto, estes problemas podem ser minimizados se os investigadores trocarem experiências e colaborarem uns com os outros e divulgarem suas pesquisas na área de turismo.

Atualmente, é imprescindível haver um planejamento da atividade turística, pois com sua ausência as localidades turísticas crescem de maneira descontrolada, isto leva a descaracterização da destinação que motiva o fluxo dos turistas. Por isto se faz necessário conhecer as aptidões e limitações do local, tanto no meio natural como no cultural e social, além de conhecer os aspectos econômicos para que se possa inserir uma atividade turística sustentável.

Sendo assim, o capítulo seguinte irá abordar os conceito de plano e planejamento que surgiram, inicialmente, na área de Administração.

\subsection{PLANEJAMENTO E PLANO}

A mudança é inerente ao ser humano. É da natureza do homem a busca por melhores condições de vida e, por isto, trabalha para atingir seu objetivo. Esta mudança requer ações ordenadas, pois um movimento desordenado pode levar a situações indesejáveis. O mesmo ocorre com as organizações que, para atingir seus 
objetivos, estabelecem as ações que devem ser implementadas, cada uma a seu tempo.

Como a organização existe em função do seu objetivo, as ações precisam ser comunicadas a todos os empregados que, atuando ordenadamente, ele seja atingido. Ao longo dos anos foram desenvolvidas várias ferramentas que são utilizadas na elaboração e comunicação das ações às pessoas envolvidas.

A revolução industrial provocou o movimento do trabalho individual ou familiar para a produção industrial. O aumento do número de pessoas envolvidas e, posteriormente, a globalização e a concorrência exigem o planejamento das ações para que os objetivos sejam atingidos. Assim, planejamento estratégico, tático e operacional passaram a fazer parte do vocabulário dos empregados.

Em administração, Oliveira (2004: 35-36), conceitua planejamento como um processo "desenvolvido para o alcance de uma situação desejada de um modo mais eficiente, eficaz e efetivo, com a melhor concentração de esforços e recursos pela empresa". Desta forma, o planejamento antecede a decisão e a ação, uma vez que envolve diversas variáveis inter-relacionadas e interdependentes. O planejamento pode ser classificado em estratégico, tático e operacional.

A palavra estratégia, derivada do grego strategos, significa "a arte do general". Importada da arte militar, em administração, a estratégia é a arte de planejar uma mudança e conduzir a organização para atingir determinados objetivos no futuro, considerando o ambiente e os recursos necessários. Desta forma, diretriz, plano, programa, projeto e atividade fazem parte do planejamento estratégico da organização (SILVEIRA JÚNIOR, VIVACQUA, 1999: 34).

Por planejamento estratégico Oliveira (2004: 47) considera "o processo administrativo que proporciona sustentação metodológica para se estabelecer a 
melhor direção a ser seguida pela empresa, visando ao otimizado grau de interação com o ambiente e atuando de forma inovadora e diferenciada".

O planejamento estratégico procura dar uma visão de onde a empresa deve chegar. Para tal, estabelece o caminho que deve ser seguido, a partir da situação atual.

Para Oliveira, "o planejamento tático tem por objetivo otimizar determinada área de resultado e não a empresa como um todo" (2004: 48). Ele considera planejamento operacional "como a formalização, principalmente através de documentos escritos, das metodologias de desenvolvimento e implantação estabelecidas" que são os planos de ação ou planos operacionais que devem conter: os recursos necessários, os procedimentos básicos, os resultados esperados, os prazos e os responsáveis pelas ações. O planejamento estratégico está relacionado aos objetivos de longo prazo da organização e o tático aos de curto prazo que afetam parte da organização (OLIVEIRA, 2004: 51).

Oliveira (2004: 35) define plano como

"um documento formal que se constitui na consolidação das informações e atividades desenvolvidas no processo de planejamento; é o limite da formalização do planejamento, uma visão estática do planejamento, uma decisão em que a relação custos versus benefícios deve ser observada".

Assim, o plano consolida as informações e atividades planejadas que, de maneira formal, deverão orientar a elaboração dos projetos e planos de ação para que os objetivos da organização sejam atingidos.

Segundo Oliveira (2004: 246), o projeto estabelece a data de início e fim da transformação, indica o responsável, o resultado a ser alcançado e quais os recursos necessários para o seu desenvolvimento. Para ele, plano de ação "é o conjunto das partes comuns dos diversos projetos, quanto ao assunto que está sendo tratado (recursos humanos, tecnologia etc.)". Os projetos representam a 
interligação entre as estratégias e o orçamento necessário para se atingir os objetivos estabelecidos. (OLIVEIRA, 2004: 253).

Mintzberg, Ahlstrand e Lampel (2000) descrevem dez escolas de pensamento estratégico que tiveram ênfase a partir da década de 60 . Cada uma teve e tem a sua importância no desenvolvimento e amadurecimento da administração nas diversas áreas de atuação. Para os autores, o planejamento deve combinar características de diferentes escolas para ser bem sucedido (2000: 270). As escolas são: design (1960), planejamento (1970), posicionamento (1980), empreendedora, cognitiva, aprendizado, poder, cultural, ambiental e configuração. As três primeiras são de natureza normativa (como são formuladas as estratégias), as seis seguintes se concentram no processo de concepção e a última reúne características dos dois grupos anteriores. A estratégia, ferramenta gerencial imprescindível, é definida segundo as suas escolas como: planejamento, modelo, posicionamento, perspectiva ou armadilha. Para os autores, a estratégia é útil para manter a organização na rota traçada, mas podem dificultar a visão periférica do ambiente em que atuam. (2000: 16-23).

O turismo se identifica mais com a escola do planejamento, divulgada por Ansoff (apud Mintzberg; Lampel, 2000), uma vez que formaliza o plano de desenvolvimento do turismo na localidade, com estreita ligação ao orçamento municipal. Para tal decompõe os planos de ação em programas visando facilitar o controle de sua execução. Tais programas propõem mudanças periódicas e incrementais, sendo renovados ou substituídos à medida que as mudanças são percebidas no ambiente, como necessidade de treinamento, de infra-estrutura etc. 
Vale ressaltar que o conhecimento da existência das demais escolas do pensamento estratégico favorece a percepção do ambiente e a análise das opções que se apresentam em cada localidade objeto de um plano de turismo.

No próximo capítulo será contextualizado a evolução dos estudos em planejamento do turismo. Para após. se iniciar a conceituação deste instrumento tão utilizado neste trabalho.

\subsection{EVOLUÇÃO DOS ESTUDOS EM PLANEJAMENTO DO TURISMO}

Os primeiros estudos em turismo foram realizados por volta de 1870 , em sua maioria nas áreas de geografia e economia.

$\mathrm{Na}$ Alemanha, por exemplo, os primeiros estudos foram com enfoque geográfico por volta de 1900 (Wolf e Jorckzek apud Rejowski, 1996: 15).

Criou-se o Centro de Pesquisas Turísticas, na Alemanha, no fim dos anos 20; um de seus representantes considerou o turismo como "uma ocupação do espaço por pessoas que afluem a determinada localidade, onde não possuem residência fixa" (Glucksmann apud Rejowski, 1996: 15).

Uma obra intitulada Fundamentos gerais do ensino do Turismo de dois professores suíços, W. Hunziker e K. Krapf, surge em 1942 e foi considerada fundamental para o estudo cientifico. Estes autores também "introduziram as primeiras idéias e o primeiro pensamento sobre uma Ciência Integral do Turismo, com a tão chamada Definição Universal, na qual o turismo é o conjunto de relações e fenômenos resultantes do deslocamento e da permanência de pessoas em localidades diferentes daquelas nas quais residem ou trabalham, contanto que tais 
deslocamentos e permanências não sejam motivados por uma atividade lucrativa principal, permanente ou temporária" (Rejowski, 1996: 16).

Nas décadas de 1960 e 1970 nos Estados Unidos da América (EUA) e em outros países, o estudo do turismo começou a aparecer nas bibliografias especializadas, nas áreas de geografia, economia, administração, sociologia e antropologia (Pearce apud Rejowski, 1996: 17).

Portanto, pode-se perceber que no campo do turismo apesar de ser uma prática antiga os estudos científicos são recentes, e utiliza-se de métodos e técnicas de outras disciplinas que têm interesse no turismo, como economia, psicologia, sociologia etc.

Assim também se deu a evolução do planejamento, que surgiu após as duas Guerras Mundiais (1914 a 1918 e 1939 a 1945) e a Revolução Russa, como conseqüência das transformações econômicas e sociais que provocaram mudanças na condição de vida das cidades, do meio ambiente e das sociedades.

Após estas transformações causadas pelas Guerras e pela Revolução Industrial os governos exerceram o controle dos problemas socio-econômicos e passaram a organizar e controlar também a economia.

O planejamento é um conjunto de ações que visam resolver problemas, com o objetivo de obter um desenvolvimento favorável, como a melhoria na qualidade de vida das populações.

O planejamento é um processo que se desenvolve ao longo de várias fases que, segundo Glasson (apud Rodrigues, 2004: 78), estas fases são:

"- Identificação do problema, ou seja, conhecimento da realidade especifica que é objeto de estudo;

- Definição de metas gerais relacionadas com o problema;

- Estabelecimento de objetivos específicos, mensuráveis, relacionados com os objetivos gerais; 
- Identificação de possíveis estrangulamentos, ou seja, de dificuldades que poderão surgir e que terão de ser enfrentadas quando da resolução do problema existente;

- Projeção da situação futura, a curto, médio e longo prazo;

- Elaboração e avaliação das alternativas a aplicar no caso das primeiras medidas se não revelarem adequadas à resolução do problema, ou de se impor uma orientação estratégica diferente;

- Elaboração do plano, documento que inclui as políticas e estratégias a seguir, servindo de guia para os responsáveis pela sua implementação".

É interessante lembrar que o planejamento deve ser contínuo e flexível, sem que seu prazo perca a validade, com acompanhamento das mudanças econômicas e sociais. É necessário fazer avaliação contínua do desenvolvimento do plano.

Para Molina e Rodrigues (2001: 79):

"O planejamento é o resultado de um processo lógico de pensamento, mediante o qual o ser humano analisa a realidade abrangente e estabelece os meios que Ihes permitirão transformá-la de acordo com seus interesses e aspirações. Disso resulta que a forma adequada de planejar consiste em analisar objetivamente uma realidade e condicional as ações ao problema".

No conceito de Boiteux e Werner (2003: 9), planejamento é “a determinação antecipada dos objetivos a serem atingidos é a decisão do que fazer, como fazer e quem executará as funções determinadas”.

O planejamento é uma atividade que envolve a intenção de estabelecer condições favoráveis para alcançar objetivos propostos. Ele tem por objetivo o aprovisionamento de facilidades e serviços para que uma comunidade atenda seus desejos e necessidades ou, então, "o desenvolvimento de estratégias que permitam a uma organização comercial visualizar oportunidades de lucro em determinados segmentos de mercado" (Harry e Spink, apud Ruschnann, 1997: 83). O planejamento pode ser entendido também como:

"Um processo que consiste em determinar os objetivos de trabalho, ordenar os recursos materiais e humanos disponíveis, determinar os métodos e as técnicas aplicáveis, estabelecer as formas de organização e expor com precisão todas as especificações 
necessárias para que a conduta da pessoa ou do grupo de pessoas que atuarão na execução dos trabalhos seja racionalmente direcionada para alcançar os resultados pretendidos." (Estol e Albuquerque s.d., apud Ruschmann, 1997: 84)

O planejamento é de fundamental importância para o desenvolvimento saudável e seguro da atividade turística. Planejar é organizar idéias e recursos para alcançar e concretizar um determinado objetivo específico, analisando pontos fortes e fracos, traçando estratégias, prevendo possíveis erros e obstáculos no decorrer do planejamento, e envolvendo participantes de um mesmo processo na tomada de uma decisão ou busca de um resultado.

Souza (apud Anjos, 2004: 60) afirma que:

“(...) planejar significa tentar prever a evolução de um fenômeno ou, para dizê-lo de modo menos comprometido com o pensamento convencional, tentar simular os desdobramentos de um processo, com o objetivo de melhor precaver-se contra prováveis problemas ou, inversamente, como forma de melhor tirar partido de prováveis benefícios".

Já a definição de plano mais utilizada é a de Bissoli (1999), ela diz que é o documento que vai materializar o planejamento e dá a ele suporte para a tomada de decisão. Deve ser revisto sempre, e deve-se estar atento às mudanças decorrentes de desastres ambientais, problemas políticos, guerras e quaisquer outros fatores que não temos qualquer controle ou influência.

Segundo Bissoli (1999: 28), o plano deve conter as seguintes etapas fundamentais: diagnóstico, prognóstico, objetivos, metas, estratégias, diretrizes, avaliação.

No turismo, o Estado é o maior responsável por todo planejamento e legislação que irá ditar as regras para um desenvolvimento do que chamamos infraestrutura básica turística, além de preservar as qualidades de suas regiões e patrimônios dos locais a serem explorados. É de fato importante fixar que para o 
desenvolvimento do turismo não podemos esquecer de uma boa relação públicoprivada, onde o Estado é o maior responsável por esse planejamento, pois cria oportunidades e condições básicas para empresas privadas atenderem e prestarem o serviço necessário ao turista. Neste contexto, Ruschmann (1997: 155) diz:

"Os objetivos das ações governamentais são de fundamental
importância: se o desenvolvimento turístico é enfocado do ponto de
vista econômico, a forma de abordagem será baseada no
mecanismo dos preços, numa visão eminentemente comercial.
Entretanto, os aspectos sociais, culturais e ambientais da atividade
não podem ser negligenciados e exigem envolvimento direto e
estudo por parte das entidades governamentais. Historicamente, o
êxito do turismo em uma destinação depende da ação do Estado."

Na gestão do turismo é essencial que, além de governo e iniciativa privada, haja uma participação de líderes comunitários, igrejas, representantes da sociedade e figuras públicas de carisma para tomada de decisões importantes que irão afetar diretamente ou indiretamente a sociedade local. No turismo, a comunidade local deve ser inserida em qualquer plano ou projeto proposto. A inserção dessa população é de extrema importância para o desenvolvimento sustentável daquela localidade, para a preservação da cultura local da comunidade, além disso, traz oportunidade de emprego e renda, cria uma cadeia de vários setores da economia em prol do turismo.

Segundo Bissoli (1998: 36):

"Os cidadãos tem obrigação de se envolver com o processo de planejamento turístico da municipalidade. Eles vivem diariamente as causas, conseqüências, e/ou efeitos do desenvolvimento da atividade turística, seja qual for seu estágio de desenvolvimento."

E Sancho (apud Bissoli,1998: 36) cita princípios fundamentais para o desenvolvimento do turismo:

“- Evolução da percepção dos efeitos do turismo.

- Capacidade de Carga. 
- Importância do consenso da comunidade local.

- Participação da Comunidade Local.

- Conscientização dos Turistas.

- Integração do elemento sócio cultural no planejamento Turístico."

No processo de planejamento turístico, deve-se levar em conta todas as variáveis existentes, pois um plano colocado em prática com falhas, além de fracassar, pode levar uma localidade a desperdiçar todo potencial que nela existe e fadar o projeto ao total fracasso causando um grande prejuízo à comunidade.

Atualmente, planejar é imprescindível para o turismo, pois traça objetivos, metas, avalia riscos e oportunidades, calcula todos os custos, identifica barreiras, estabelece ações, estabelece prazos, o que resulta num plano com melhores chances de ser bem sucedido.

Nas ciências sociais e humanas em geral, as definições não são únicas como nas ciências exatas, e podem ser transmitidas e interpretadas de várias formas, sob vários aspectos. O turismo tem vários conceitos de planejamento do turismo e planos de desenvolvimento e serão apresentados alguns deles, a seguir, para se entender os princípios básicos do que representam.

\subsection{PLANEJAMENTO EM TURISMO E PLANOS DE DESENVOLVIMENTO}

A atividade turística traz transformações ao destino e podem ser positivas ou negativas para a comunidade local como: crescimento populacional; novas tecnologias, redes de comunicação e redes de transporte etc. Estas transformações são mais drásticas quando há um crescimento desenfreado do fluxo turístico.

Isto demonstra a importância de um planejamento para que o turismo se desenvolva em uma localidade, contribua para o crescimento do fluxo turístico de 
maneira controlada e proporcione melhoria nas condições econômicas, sociais e ambientais da região turística.

Na visão de Antunes (2006: 203) "na sociedade contemporânea, o turismo tem ocupado cada vez mais o universo correspondente ao lazer, lazer este vivenciando enquanto espaço de realização dos indivíduos, associados à idéia de liberdade em relação ao uso do tempo livre".

Apesar do turismo ser "mercadoria", atualmente ele tem essa conotação de ser realização do lazer, aproveitamento do tempo livre. Por um lado se vincula o lazer "ao consumo e ao poder dos meios de comunicação de massa" e por outro lado, "contribuem para construir um 'ideal' de diversão" (Antunes, 2006: 204).

As comunidades receptoras do turismo, inicialmente, se entusiasmam com a idéia de receber cada vez mais turistas, pois a atividade aponta um crescimento da renda da população local. Entretanto, essa fase de entusiasmo passa assim que começa a conviver com o turismo de "massa" e os impactos que este causa. Percebem que o turismo "massivo" tem seu lado positivo e negativo, que nem sempre traz vantagens para a população local que não possuem um planejamento estratégico. Como afirmam os autores Lage e Milone (apud Antunes, 2006: 206):

"é comum que a percepção do turismo pelos residentes dos paises receptores altere-se ao longo do tempo. Historicamente, o turismo começa sem qualquer planejamento formal e é bem visto pelos cidadãos dos paises de destinação por causa da promessa de benefícios econômicos e em virtude da curiosidade humana. Em muitos casos, todavia, o entusiasmo desaparece quando o número de turistas aumenta, as facilidades tornam-se insuficiente e a pobreza é agravada. A população local passa a compreender a sua dependência econômica do turista e que não mais controla ou mesmo é consultada sobre o destino de seu meio ambiente [...]".

O turismo de "massa" é: "caracterizado pelo deslocamento e pela permanência nos núcleos receptores de um grande número de visitantes". (Ruschmann, 1997: 155) 
Esse fluxo de "massa", portanto, causa graves alterações sociais e ambientais. Entretanto, desejos e necessidades de consumir esse lazer cresce cada dia mais na sociedade contemporânea, querendo utilizar-se dos bens e serviços de entretenimento que são oferecidos no turismo.

Portanto, o turismo tem que se desenvolver de forma sustentável. O "turismo sustentável" é um conceito recente que diz que o turismo deve acontecer sem que o meio seja prejudicado.

Sendo assim, remeter um significado sobre desenvolvimento não é fácil. Para desenvolvimento sustentável é ainda mais complicado. Becker (apud Alexandre, 2003: 5) diz que desenvolvimento é algo positivo e que “(..) desenvolver-se seria forçosamente seguir em uma direção ascendente, rumo ao mais e ao melhor". Podese perceber que o desenvolvimento precisa de incentivo para acontecer, pois ele não evolui livremente para que o crescimento aconteça de forma favorável para uma localidade. Promovendo sua "auto-sustentabilidade" é importante ter uma interação entre governo, comunidade e meio-ambiente. Mostrando que o desenvolvimento é econômico, social e territorial, segundo Cavaco (apud Alexandre, 2003: 7).

Neste sentido a OMT define turismo sustentável:

"O desenvolvimento do turismo sustentável atende às necessidades dos turistas de hoje e das regiões receptoras, ao mesmo tempo em que protege e amplia as oportunidades para o futuro. É visto como condutor ao gerenciamento de todos os recursos, de tal forma que as necessidades econômicas, sociais e estratégias possam ser satisfeitas sem desprezar a manutenção da integridade cultural, dos processos ecológicos essenciais, da diversidade biológica e dos sistemas que garantem a vida".

Isto quer dizer que para o turismo se desenvolver é preciso conservar e preservar os recursos naturais, históricos e culturais da sociedade, de modo a não gerar degradação ao meio ambiente e à sociedade da localidade onde se insere para que futuramente não faltem recursos para serem apreciados no turismo. 
"No turismo, o plano de desenvolvimento constitui o instrumento fundamental na determinação e seleção das prioridades para a evolução harmoniosa da atividade, determinando suas dimensões idéias para que apartir daí, possa-se estimar, regular ou restringir sua evolução" (Alexandre, 2003: 8)

Deste modo, valorizando as particularidades locais, o desenvolvimento pode passar a ser inserido nas regiões periféricas de forma a aumentar o raio de alcance do desenvolvimento econômico da atividade turística.

Portanto, segundo Petrocchi (1998: 19), "planejamento é a definição de um futuro desejado e de todas as providencias necessárias a sua materialização".

Para que as tarefas e os objetivos sejam cumpridos se faz necessário planejar para que sejam melhor realizadas e atingidas a tempo. Assim, é preciso conhecer seu espaço e tempo.

O dono de uma sorveteria, por exemplo, precisa monitorar seus fregueses para saber a quantidade de suprimentos a serem adquiridos, acompanhar a reação dos clientes a um sabor e outro, para ampliar a oferta do sabor mais procurado e suspender a oferta do menos consumido. Isto é planejar, é a tomada de decisão e as ações que são tomadas todos os dias em busca do aperfeiçoamento para melhor atender as necessidades dos clientes, mesmo que o processo seja intuitivo ou por tentativas.

Organizações de grande porte não devem fazer tomada de decisão intuitivamente ou por tentativas, pois o investimento em um produto é muito alto. Por este motivo, se faz um planejamento estratégico.

De acordo com Petrocchi há três níveis de planejamento: estratégico, tático e operacional.

"O nível estratégico se refere ao direcionamento da organização. No nível operacional, cuida-se dos procedimentos, das tarefas mais simples. Entre os dois níveis há todo um processo de compreensão 
da organização e tomadas de decisão para onde ela deve ser orientada".

Pra uma melhor visualização Chiavenato (apud Petrocchi, 1998: 25) montou a tabela 1 abaixo, que nos mostra as características que cada nível possui:

Tabela1: Características do Planejamento.

\begin{tabular}{|c|c|c|c|}
\hline \multicolumn{4}{|c|}{ Características do Planejamento } \\
\hline $\begin{array}{l}\text { Tipos de } \\
\text { Planejamento }\end{array}$ & Abrangência & $\begin{array}{l}\text { Exposição ao } \\
\text { tempo }\end{array}$ & Nível de decisão \\
\hline Estratégico & $\begin{array}{l}\text { Organização como um } \\
\text { todo }\end{array}$ & Longo prazo & Alta administração \\
\hline Tático & Departamento ou setor & Médio prazo & Média Gerência \\
\hline Operacional & Tarefa ou operação & Curto prazo & Supervisão \\
\hline
\end{tabular}

Fonte: Chiavenato (apud Petrocchi, 1998: 25)

No turismo o planejamento também é extremamente necessário pois regiões de grande beleza cênica, cidades históricas e de cultura marcante estão sendo destruídas aos poucos. Este potencial turístico precisa ser preservado e conservado hoje, para que no futuro não esteja completamente destruído.

O que acontece hoje, na maioria das vezes, é que a mídia fala sobre uma região ou uma cidade num jornal ou novela, e as pessoas esperam que aquela localidade esteja pronta para recebê-los como turistas. Entretanto, a localidade não esta pronta e não possui um planejamento para ter um desenvolvimento positivo com o turismo. Por este motivo, estes destinos da "moda" são prejudicados e destruídos gradativamente. Assim como a qualidade de vida da população local.

Peter Druker (apud Petrocchi, 1998: 33) alerta: 
“... o planejamento não representa o domínio mental do futuro (...) Qualquer tentativa neste sentido é insensatez. As criaturas humanas não podem prever nem controlar o futuro. A pretensão de assenhorear-se do futuro é infantilidade e nossos esforços nesse sentido só podem desacreditar o nosso trabalho. Pode-se partir logo da conclusão de que a previsão, além dos prazos mais curtos, não merecem respeito nem vale a pena. O planejamento a longo prazo é necessário justamente em virtude da nossa incapacidade de prever. Existe, porém, outra razão mais poderosa que faz constatar qual será o mais provável curso dos acontecimentos ou, no Maximo, apurar uma série de probabilidades. Todavia, o problema empresarial é o único capaz de modificar as possibilidades, uma vez que o universo da empresa não é composto de matéria, mas de valor. Com efeito, principal contribuição da empresa, aliás a única que tem como recompensa o lucro, é fazer com que haja uma ocorrência exclusiva, a inovação que altere as probabilidades".

Para Petrocchi (1998: 51) o planejamento é dividido nas seguintes etapas com suas ações a serem seguidas:

“1) Análise Macroambiental: conhecer o entorno à organização, o mercado e a situação interna.

2) Elaboração de diagnóstico: Sumario que reflete os levantamentos da analise macroambiental.

3) Define os objetivos: o que se quer atingir.

4) Determinar as prioridades: o que é mais importante; em que ordem.

5) Identificar os obstáculos, as dificuldades: listar quais são; sua intensidade;influencia sobre os resultados.

6) Criar os meios, os mecanismos: visam minimizar os obstáculos; analisar e escolher alternativas.

7) Dimensionar os recursos necessários: quantificar os recursos; em que ordem de necessidade.

8) Estabelecer responsabilidades: Especificar volumes, padrões, fluxos, áreas críticas, etc.

9) Projetar cronograma: Definir prazos de execução, volumes de produção, custos, parâmetros, etc.

10) Estabelecer pontos de controle: escolher áreas-chave; estabelecer critérios."

O autor também apresenta a estrutura para se elaborar o plano positivamente

em uma localidade, conforme figura 1 abaixo (1998: 68): 


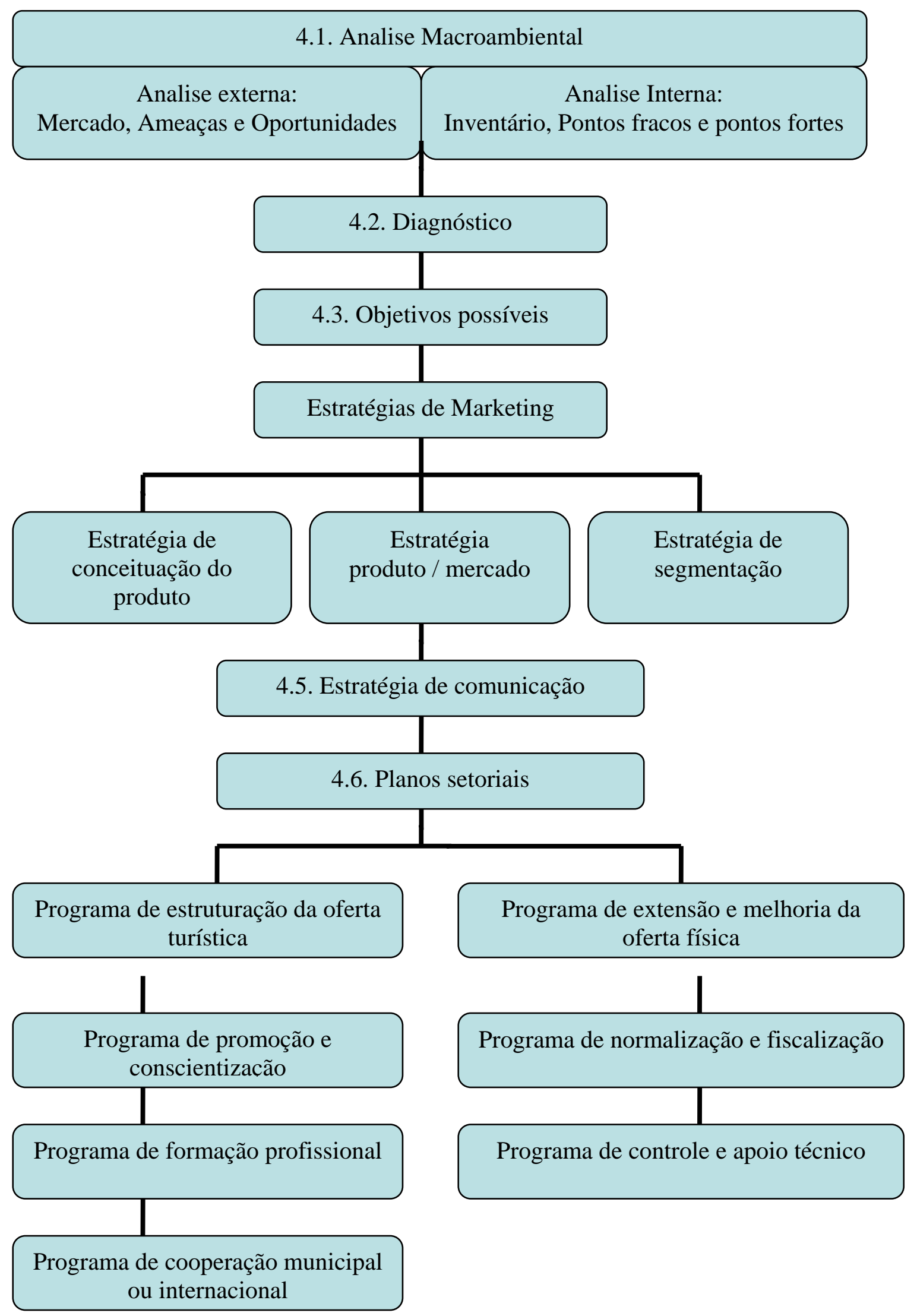

Figura1: Elaboração positiva de um plano Fonte: Petrocchi (1998: 68) 
Para Bissoli (1999: 26), planejamento é um processo que permite revisão e correção da direção a todo o momento, sendo assim um processo dinâmico, constante e mutável.

Concordando com os autores Holanda e Carvalho (apud Bissoli, 1999: 25) em relação ao que se entende por planejamento:

“- Processo de tomada de decisão que se destina a produzir um - ou mais de um - estado futuro desejado e que não deve ocorrer a menos que alguma coisa seja feita.

- Processo de determinação dos objetivos e dos meios necessários para sua consecução.

- Previsão de estudos futuros e seleção daquilo que se espera produzir em condições ótimas.

- Instrumento que facilita as decisões sobre o que fazer no futuro.

- Estabelecimento de modelos normativos de que pode ser definido como teorias operacionais.

- Mecanismo orientado para o futuro que se desenvolve no tempo e no espaço.

- Atividade que envolve a intenção de estabelecer condições favoráveis para que se possa alcançar os objetivos propostos.

- Processo que consiste em determinar os objetivos do trabalho, ordenar os recursos materiais e humanos disponíveis, determinar os métodos e as técnicas aplicáveis, estabelecer as formas de organização e expor com precisão todas as especificações necessárias para que a conduta da pessoa ou do grupo de pessoas que atuar na execução dos trabalhos seja racionalmente direcionada para alcançar os resultados pretendidos.

- Processo de distribuição ótima dos recursos e dos meios, tendo em vista objetivos definidos.

- Atividade, e não algo estático, que precisa ser coordenada para alcançar o objetivo proposto".

Para que o planejamento se "materialize" se faz necessário um plano que para ser elaborado devem ser observadas as seguintes etapas:

- Estabelecimento da missão da empresa ou organização, que seria o propósito e a finalidade da existência da mesma.

- A definição das metas, que é a maneira em que se alcançará a missão.

- Elaborar os objetivos, que seriam as tarefas específicas com o estabelecimento de prazo para cumpri-lo. 
- Diagnóstico:

“...Encaminha para a sistematização de um acúmulo de informações quantitativas sobre a situação atual e suas tendências - como detectados primeiros obstáculos a um crescimento mais acelerado que contribuam para definir uma política de desenvolvimento planejado que se proponha a diminuí-los ou eliminá-los" (Bissoli, 1999: 29).

- Prognóstico: "Fundamenta-se em uma previsão - ou em projeções de tendências - que visualiza as potencialidades ou possibilidades de crescimento" (Bissoli, 1999: 29).

- Objetivos: faz-se após o diagnóstico, considerando as alternativas de crescimento do setor ou intensidade $e$ as modalidades de desenvolvimento que se quer alcançar.

- Metas: Expressar quantitativamente as definições do que se pretende.

- Estratégias entendem-se por:

"- A maneira como se deve conduzir uma atividade.

- A maneira de alcançar satisfatoriamente os objetivos fixados.

- A maneira de se aproximar da situação desejada.

- Alternativas á ação". (Ignarra apud Bissoli, 1999: 32)

- Diretrizes: "Orientações ou regulamento para aplicação ou execução das estratégias" (Bissoli, 1999: 33).

- Avaliação: Determina se os objetivos foram atingidos, e caso não os tenha se aponta os motivo.

Após a elaboração, o plano deve ser apresentado aos responsáveis encarregados pela execução para que se possa discutir e aprovar o que foi apresentado. Assim, também se deve apresentar à comunidade local para que possam estar a par do desenvolvimento do plano e colaborar em sua execução. 
Para Dencker (1998: 34), planejamento turístico é:

"...um processo que analisa a atividade turística de um determinado espaço geográfico, diagnosticando seu desenvolvimento e fixando um modelo de atuação mediante o estabelecimento de metas, objetivos, estratégias e diretrizes com os quais se pretende impulsionar, coordenar e integrar 0 turismo ao conjunto macroeconômico em que está inserido."

Para Anjos (2004: 61):

"o planejamento se configura como um processo cíclico retroalimentado constantemente, e mesmo se expressando linearmente no tempo, possibilita a geração de propostas e soluções num ambiente contínuo de tomada de decisões, tendo um caráter muito mais complexo do que uma seqüência de atividades".

Segundo ele, este processo de planejamento deve ser feito com a participação da população local, para dar "suporte de realidade" ao desenvolvimento do planejamento, em todas as etapas: concepção, elaboração e controle. Deve-se compartilhar todas as informações com o governo e a comunidade, fazendo com que a manutenção seja menos freqüente e mais profunda.

Anjos (2004: 88) diz que "o desenvolvimento turístico deve se basear no equilíbrio entre a conservação ambiental e cultura, a viabilidade econômica e a justiça social". Isto quer dizer que este desenvolvimento contribui para a melhoria de vida da população e para a preservação do meio ambiente, minimizando os impactos ambientais e sociais.

Planejar deve estar ligado diretamente às políticas de desenvolvimento do setor turístico. A elaboração de um planejamento turístico traz alguns benefícios, tais como (Bissoli, 1999: 33):

“- Definição de objetivos para o desenvolvimento do turismo e como alcançá-los.

- Formas de desenvolver os recursos naturais e culturais e mantê-los indefinidamente conservados para o futuro, e no presente. 
- Integração do turismo nas políticas de desenvolvimento globais e nos padrões entre turismo e outros setores econômicos.

- Fornecimento de uma base racional para tomada de decisão para os setores publico e privado em relação ao desenvolvimento turístico.

- Esforços para o desenvolvimento coordenado de todos os muitos elementos do setor do turismo.

- Otimização e equilíbrio dos benefícios econômicos, ambientais e sociais do turismo, com distribuição eqüitativa desses benefícios para a sociedade, minimizando possíveis problemas no setor.

- Provisão de uma estrutura física que oriente o desenvolvimento da atividade turística.

- Estabelecimento de diretrizes e padrões para planos detalhados de áreas de desenvolvimento do turismo.

- Implementação efetiva da política de desenvolvimento do turismo e do plano de administração contínua do setor de turismo.

- Esforços de setores público e privado para investimento no desenvolvimento do turismo.

- Oferta de um monitoramento contínuo do desenvolvimento do turismo".

O envolvimento da comunidade no planejamento turístico é essencial, pois pode avaliar os impactos das atividades planejadas sobre cada componente dentro do ambiente. Além disso, é a população local que vive as causas e conseqüências, diariamente, do desenvolvimento das atividades turísticas.

Após contextualizar o planejamento, conhecer seus conceitos, tanto na administração quanto no turismo, o capitulo seguinte irá nortear as análises das principais características metodológicas dos Planos de Desenvolvimento Turísticos. 


\section{ESTUDO DOS PLANOS DE DESENVOLVIMENTO INTEGRADO DO TURISMO SUSTENTÁVEL DO PÓLO VALE DO JEQUITINHONHA E DA ÁREA PRIORITÁRIA SERRA GAUCHA}

No estudo abaixo se analisa os Planos de Desenvolvimento Integrado do Turismo Sustentável Pólo Vale do Jequitinhonha e Área Prioritária Serra Gaúcha na visão municipal que é trabalhada pela autora Bissoli (2002) que nos mostra a importância do planejamento em cada destinação turística; na visão sistêmica utilizada por Petrocchi (1998) que coloca o planejamento como um sistema turístico que integra tudo o que envolve o turismo como as organizações, os turistas, a comunidade local etc; e por fim na visão sustentável de Ruchmann (1997) que diz que o desenvolvimento de toda a atividade turística pode ser sustentável de modo a trazer desenvolvimento para a localidade e seu entorno.

Em cada uma destas visões serão abordados os itens abaixo, com a finalidade de mostrar suas diferenças e semelhanças:

- Estrutura para plano de desenvolvimento

- Características mais importantes para o planejamento

- Aspectos de turismo sustentável

\subsection{DESCRIÇÕES DOS PLANOS DE DESENVOLVIMENTO DO TURISMO}


$\mathrm{Na}$ descrição dos planos de desenvolvimento turístico foram selecionados alguns tópicos para que os planos sejam devidamente apresentados. Os tópicos são: objetivo ou diretriz ;cidades que cada plano contempla; a abrangência no sentido de saber se os visitantes da localidade são de nível nacional ou internacional; os atrativos existentes em cada localidade; aspectos de sustentabilidade, de infra-estrutura, socioeconômicos, culturais; nível de escolaridade da população e dos empresários; estruturas de desenvolvimento dos setores público e privado e que se faz imprescindível para o desenvolvimento do turismo de cada localidade.

\subsubsection{Plano de desenvolvimento integrado do turismo sustentável: Pólo Vale do Jequitinhonha}

Este plano de desenvolvimento, foi elaborado pelo Centro de Desenvolvimento de Estudos Econômicos e Sociais da Fundação João Pinheiro em 2004, atendendo à demando da Secretaria de Estado de Turismo de Minas Gerais, que é responsável pelo programa Prodetur/NE II.

A equipe técnica que coordenou o trabalho integrava, principalmente, consultores em turismo, além de profissionais de outras áreas de atuação membros da Fundação João Pinheiro (FJP) e da Secretaria de Estado do Turismo (Setur).

Realizou a seleção de algumas cidades da área do Pólo de desenvolvimento, pois o volume de municípios que pertencem a ele é grande. São trinta municípios e foram selecionados nove, que são: Capelinha, Couto de Magalhães de Minas, Diamantina, Felício dos Santos, Itamarandiba, Minas Novas, São Gonçalo do Rio Preto, Serro e Turmalina.

O Plano compreende os seguintes volumes: 
- Volume 1 - Resumo Executivo

- Volume 2 - Parte 1 - Área de Planejamento - Parte 2 - Dinâmica Econômica e Social

- Volume 3 - Infra-estrutura

- Volume 4 - Patrimônio Histórico e Cultural

- Volume 5-Aspectos Socioambientais

- Volume 6-Capacidade Institucional Municipal

- Volume 7 - Capacitação do Setor Privado envolvido com o Setor Turístico

- Volume 8-Parte 1-Produtos Turísticos e Atrativos

- Parte 2 - Qualidade e Oferta de Alojamento e outros Equipamentos Turísticos

- Volume 9 - Parte 1 - Educação da Comunidade para o Turismo - Parte 2 - Capacitação do Profissional para o Turismo

- Volume 10 - Parte 1 - Perfil do Turista

- Parte 2 - Gastos Turísticos

- - Parte 3 - Demanda Atual e Potencial

- Volume 11 - Parte 1 - Estratégias de Desenvolvimento Turístico - Parte 2 - Quadros Prospectivos

- Volume 12 - Quadros Prospectivos: Projeção do Emprego, por Município

- Volume 13 - Plano de Ação

A metodologia de elaboração do plano demandou o levantamento de vários tipos de dados, primários e secundários, sobre a região. Foram feitos inventário turístico, pesquisa de demanda atual e potencial, diagnóstico, estratégias e plano de 
ação e reuniões, que tiveram por objetivo promover a participação pública no processo de elaboração e validação.

O Plano possui como objetivo:

"Enfrentar os principais obstáculos ao desenvolvimento do turismo sustentável, visando ao aproveitamento das potencialidades da região para a consolidação das várias formas de atividades turísticas apoiadas em melhor aproveitamento das riquezas e particularidades de seu quadro natural, duas formas de estratégias e ações são aqui propostas" (Fundação João Pinheiro, 2004).

E a diretriz geral deste plano é :

"planejar ações integradas e desenvolver o turismo da Área de forma sustentável, com foco no turismo histórico natural conjugado com o turismo voltado para atrativos naturais, fixando Diamantina, Serro e São Gonçalo do Rio Preto como destinos principais da região e os demais municípios como destinos que apresentam atrativos pontuais complementares" (Fundação João Pinheiro, 2004).

Os atrativos da região são: edificações, igrejas antigas, conjuntos históricos, monumentos tombados, unidades de conservação (parques e reservas), manifestações culturais, artesanato, gastronomia e eventos de pequeno porte.

O pólo contempla abrangência nacional.

Quanto ao aspecto sustentável, falta tratamento e reciclagem do lixo, necessita ampliação da rede de esgoto, despoluição de córregos e rios, abastecimento de água e preservar os recursos naturais.

Quanto aos aspectos de infra-estrutura, possui precária infra-estrutura básica (água e esgoto, abastecimento de água e saneamento), sinalização básica e turística precária, baixa densidade viária, ausência de pavimentação asfáltica e necessita ampliar e melhorar o aeródromo.

Quanto aos aspectos sócio-econômicos, falta de atenção básica à saúde, alta taxa de analfabetismo, alto índice de população rural, falta perspectiva econômica, a 
condição de vida é baixa, a renda está abaixo da média estadual, possui baixo Índice de Desenvolvimento Humano e a base da economia é agropecuária.

Quanto aos aspectos culturais, possui manifestações folclóricas, centro histórico com edificações de arquitetura colonial, alguns destes imóveis são tombados, possui museu e igrejas.

Quanto aos atrativos naturais, possui parques estaduais e cachoeiras.

A gastronomia é tipicamente mineira, tem a receita do queijo do Serro que é tombado como patrimônio imaterial da humanidade.

Quanto ao nível de escolaridade, os empresários do ramo turístico possuem nível médio ou superior. A mão de obra possui baixa escolaridade e a capacitação profissional é precária.

A estrutura de desenvolvimento do setor público necessita de políticas públicas para fortalecer o turismo, os serviços e os negócios e consolidar a capacidade institucional (gestão e gerência municipal).

A estrutura de desenvolvimento do setor privado é constituído por poucas microempresas, a maioria no segmento de alimentação, as pousadas são a maioria no segmento hoteleiro e proporcionam integração dos turistas com o ecoturismo e o turismo rural.

É imprescindível para o desenvolvimento do turismo:

- investimento em infra-estrutura básica;

- financiamento com juros baixos,

- qualificar mão de obra;

- gerir melhor as organizações e os municípios;

- o setor público necessita investir na atividade turística;

- parcerias e associações empresariais; 
- implementar sistema de qualidade nas organizações.

A seguir será apresentado o Plano de desenvolvimento integrado do turismo sustentável da Área Prioritária Serra Gaúcha.

\subsubsection{Plano de desenvolvimento integrado do turismo sustentável: Área Prioritária Serra Gaúcha}

Este plano de desenvolvimento, do Governo do Rio Grande do Sul, foi elaborado em 2005 por uma equipe multidisciplinar. A equipe técnica que coordenou o trabalho integrava, além de turismólogos, sociólogos, engenheiros, arquitetos, administradores, economistas, geógrafos e, biólogos que trabalharam junto à Secretaria da Coordenação e Planejamento e a Secretaria de Turismo, Esporte e Lazer.

Foi realizada a seleção da área prioritária, efetuado o levantamento das características básicas da área escolhida e em seguida o diagnóstico da situação atual do turismo local. Feito o diagnóstico, levantou-se cenários, impactos e definiuse as estratégias adequadas para a área.

O diagnóstico detalha as características básicas da área prioritária, verificando localização, acessibilidade, características físico-territoriais, dinâmica sócio-econômica, estrutura urbana, infra-estrutura básica, equipamentos urbanos e comunitários, aspectos sócio-ambientais e gestão municipal.

Outro ponto importante é o mapeamento da situação atual do turismo na região considerando a demanda, atrativos e produtos, a oferta e a qualidade dos alojamentos e outros equipamentos turísticos, o grau de educação para o turismo, capacitação profissional, serviços públicos de apoio e gestão. 
Observa-se no plano, uma pesquisa bibliográfica concentrada em dissertações e outros trabalhos acadêmicos que tiveram como objeto a região em questão e produziram relatórios detalhados de diversos aspectos tais como: acessibilidade, características físico-territoriais, sócio-ambientais, econômicos, sustentabilidade, entre outros. O Plano serviu-se também de dados obtidos por diversos órgãos do Governo do Rio Grande do Sul, além de outros colhidos pelo Programa Nacional de Municipalização do Turismo.

O objetivo geral do Plano é de atrair o maior número de turista de fora do Estado

As cidades de turismo consolidado são: Gramado, Canela, Caxias do Sul, Bento Gonçalves.

As cidades de turismo emergente são: Jaquirana, Antônio Prado, Bom Jesus, São José dos Ausentes, Cambará do Sul, São Francisco de Paula, Nova Petrópolis, Farroupilha, Flores Cunha e Garibaldi.

Os atrativos da região são: uma área de cultura alemã (comércio de couro e malhas), colônias italianas (costumes, tradições e arquitetura), vinícolas, gastronomia, eventos de grande porte, unidades de conservação de excelência (parques e reservas).

O pólo contempla abrangência nacional e internacional.

Quanto ao aspecto sustentável, apresentam-se algumas ações necessárias para consolidar este plano. As ações são: monitorar a exploração sustentável dos recursos naturais e culturais, inserir a população local, despoluir córregos e rios, conscientizar a comunidade da importância da conservação dos valores culturais e ambientais, garantir condições adequadas de saneamento e consolidar o cluster. 
Quanto aos aspectos de infra-estrutura, as cidades de turismo consolidado possuem acesso viário e sinalização satisfatórios, bem como aeroportos e malha ferroviária. As cidades de turismo emergente possuem acesso e sinalização precários. Apenas algumas cidades de turismo emergente não possuem abastecimento de água e não possuem tratamento de fossas sépticas. A urbanização é superior á média do estado.

Quanto aos aspectos sócio-econômicos a base da economia é constituída por indústrias e serviços. Há crescimento da oferta de serviços em empresas de pequeno porte. A renda é acima da média estadual para as cidades maiores. A população é predominantemente urbana com bom nível desenvolvimento humano, baixa taxa de analfabetismo. As cidades maiores possuem melhor tratamento de saúde. Nos municípios menores, a renda, a saúde e a educação deixam a desejar. Há restrições de informações sobre economia do turismo, perfil e fluxo de turistas.

Quanto aos aspectos culturais, algumas cidades possuem imigrantes italianos ou alemães com arquitetura, gastronomia, usos e costumes típicos em comunidades urbanas e rurais. Possui trem a vapor, museus, centros históricos, igrejas, artesanato e manifestações culturais como o chimarrão.

Quanto aos atrativos naturais, possui parques estaduais.

Quanto ao nível de escolaridade, alto nível de escolaridade e capacitação da dos empresários e da mão de obra nas cidades maiores.

Quanto à estrutura de desenvolvimento do setor público, possui unidades de conservação com boa infra-estrutura. As ações municipais não são articuladas e as secretaria municipais têm baixa capacidade de administração.

Quanto à estrutura de desenvolvimento do setor privado possui alta taxa de hospedagem, entretanto a utilização de casa de parentes também é elevada. Foi 
feito investimento em equipamentos e leitos. O custo de divulgação dos produtos é alto.

É imprescindível para o desenvolvimento do turismo:

- controlar a urbanização desenfreada e a pressão exercida sobre os equipamentos urbanos;

- regular o fluxo turístico;

- qualificar os produtos turísticos e da população empregada;

- incentivar plano de manejo sustentável;

- melhorar a eficiência da gestão tributária.

A seguir serão apresentadas as visões de planejamento de turismo.

\subsection{VISÕES MUNICIPAL, SISTÊMICA E SUSTENTÁVEL}

Apresentação das visões de planejamento do turismo abordadas por diferentes autores.

\subsubsection{Visão Municipal}

No âmbito da visão municipal de Bissoli (2002), tem-se a percepção de que o desenvolvimento do turismo está ligado aos problemas urbanos da localidade, pois o desenvolvimento turístico não acontece sem que os setores sócio-econômicos e ambientais se desenvolvam também. Por este motivo, o planejamento municipal 
ocorre quando o município não se isola da realidade e se integra a uma região, mas passa a assumir suas próprias características para que se desenvolva.

Este processo somente terá sucesso se a comunidade local e órgãos institucionais se envolverem no processo.

A comunidade necessita se envolver em todos os processos de planejamento e implementação, assim como os órgãos institucionais e as organizações existentes. Estes dois últimos precisam estruturar sua administração, estabelecer políticas com base no turismo, enfim planejar os passos que vão seguir para contribuírem com o desenvolvimento do turismo favoravelmente. A estrutura de planejamento adotada por Bissoli (2002) possui as seguintes etapas: fazer diagnóstico e prognóstico; elaborar objetivos e metas. A partir destes, elabora-se estratégias; estabelece-se as diretrizes que são as orientações para se cumprir as estratégias e, por fim, faz-se a avaliação.

Os dois planos possuem: diagnóstico, prognóstico, objetivos, metas e estratégias. O plano de desenvolvimento do Vale do Jequitinhonha possui diretriz, mas não mostra como será feita a avaliação. Já o plano de desenvolvimento da Serra Gaúcha não possui diretriz e também não diz como será feita a avaliação do plano.

Bissoli não trabalha com a abordagem do controle do plano, que é imprescindível para o planejamento de uma localidade. O controle faz com que o plano seja renovado no momento que se fizer necessário, pois nem tudo o que se coloca num plano inicial se tem sucesso. Às vezes ocorre algum problema em um determinado setor que não foi previsto inicialmente. 
Para a autora a característica mais importante no planejamento é a participação da comunidade, das organizações e do governo no processo do planejamento e na implementação do plano. E para que a população, organizações e governo participem juntos deste processo é necessário que estes se conscientizem da importância do turismo para a localidade.

\subsubsection{Visão Sistêmica}

A visão sistêmica é abordada por Petrocchi (1998) no que diz respeito ao planejamento do turismo. Ele trata o planejamento do turismo como sendo um sistema turístico onde este sistema é composto por tudo que se encontra na localidade. A própria cidade, as ruas, as edificações, os atrativos, sua população, tudo o que está disponível para que haja uma interação com o turista.

O turista é somente o cliente que se encontra na localidade para consumir o que está sendo ofertado. Este avalia, a todo momento, aquilo que ele consumir, como por exemplo, transporte, hotéis, gastronomia, lazer etc.

Pode-se perceber que os dois planos de desenvolvimento esperam que haja interação entre o turista e a localidade, a localidade e a população que nela habita, a população e o plano que foi elaborado etc. Portanto, na abordagem sistêmica é importante que haja interação do meio externo com o meio interno e entre o turista e o sistema turístico.

A estrutura do planejamento é a seguinte: análise macroambiental que são as análises externa (mercado, ameaças e oportunidades) e interna (inventário, pontos 
fracos e fortes). A partir destas informações é feito o diagnóstico de onde se definem os objetivos e as estratégias de comunicação para se promover e vender o produto.

Os planos setoriais são os últimos itens da estrutura e são subdivididos em: estruturação da oferta, expansão e melhoria da oferta física, promoção e conscientização, normalização e fiscalização, formação profissional, controle e apoio técnico e coordenação municipal.

Nos dois planos a estrutura é basicamente a mesma apresentada por Petrocchi, somente não foram expostas as estratégias de comunicação para promover o plano dentro das respectivas localidades, nem a forma que será feita o controle do plano.

Para o autor, as características mais importantes no planejamento são a participação da comunidade no turismo e a qualidade total, que é a qualidade nos serviços oferecidos pela localidade. Petrocchi (1998) não aborda detalhadamente a questão da sustentabilidade, citando apenas que é importante que se preserve o meio das destinações que são exploradas pelo turismo.

\subsubsection{Visão Sustentável}

Na visão sustentável de Ruschmann (1997) o planejamento é uma atividade que estabelece condições favoráveis para o desenvolvimento sustentável do turismo. Este planejamento é que determina a metodologia a ser utilizada para se ordenar os recursos turísticos de maneira a se atingir os objetivos desejados, estabelecendo uma ordem de prioridades de modo que a evolução da atividade 
turística aconteça harmoniosamente. Sendo assim, com um planejamento bem elaborado soluciona-se com maior eficiência e eficácia problemas futuros, ou mesmo evitando-os.

O planejamento turístico tem que integrar e relacionar os aspectos ecológicos, sociais, econômicos e culturais para ser bem elaborado, minimizando os impactos causados pelo turismo. Neste sentido, se faz necessário citar a definição de desenvolvimento sustentável elaborado pela Comissão Mundial sobre Meio Ambiente e Desenvolvimento (CMMAD):

"Um processo de transformação, no qual a exploração dos recursos, a direção dos investimentos, a orientação da evolução tecnológica e a mudança institucional se harmonizam e reforçam o potencial presente e futuro, a fim de atender as necessidades e aspirações humanas".

Para que a atividade turística se desenvolva sustentavelmente em uma localidade é necessário, também, que se encontre um equilíbrio com os interesses econômicos que são estimulados pelo turismo, segundo Ruschmann, integrando a economia à sociedade e ao meio ambiente, contribuindo para a melhoria da qualidade de vida de toda população.

A autora propõe como estrutura de planejamento:

- identificar o problema, definir objetivos e metas e também elaborar um inventário contendo o levantamento dos componentes que integram a oferta e a demanda turística.

- A caracterização da área que é composta pela delimitação da área a ser estudada, aspectos históricos, econômicos, sociais e de infra-estrutura turística, turismo receptivo e emissivo, analisando a oferta e a demanda considerando a vocação para o turismo da destinação. Avaliando os pontos fortes e fracos, oportunidades e ameaças. 
- Diagnosticar, prognosticar, traçar diretrizes, determinar prazos e definir as ações. Esta estrutura de planejamento apresentada pela autora é bastante detalhada e é a estrutura que mais se parece com a estrutura do dois planos de desenvolvimento que estão sendo estudados.

As características mais marcantes para a autora são: a importância de se envolver a comunidade da destinação no processo de planejamento, mas, principalmente, dar ênfase à sustentabilidade no turismo, no planejamento, no meio ambiente etc.

O turismo pode se tornar a principal fonte de renda de uma localidade, mas pode degradar todo o meio ambiente, cultura, tradição, se o planejamento não for adequado à localidade. Portanto, os recursos turísticos são finitos, tendo que restringir ou monitorar o uso ou visitação de cartas áreas da destinação.

Para a autora, turismo sustentável e desenvolvimento sustentável tem seus conceitos ligados à sustentabilidade do meio ambiente, pois estes dependem da preservação dos recursos oferecidos. 


\section{CONSIDERAÇÕES FINAIS}

Esta pesquisa, estuda as metodologias existentes para planos de desenvolvimento do turismo, demonstra que o planejamento se constitui numa ferramenta para as administrações municipais, servindo também como suporte e subsidio para a tomada de decisões, para atender os desejos dos turistas. Este se mostra imprescindível para o sucesso de qualquer empreendimento, seja pessoal, no turismo ou outra área. $\mathrm{Na}$ área de turismo, ressaltem-se os seguintes aspectos do planejamento estratégico:

- o que o município pode fazer em relação ao tipo de turismo da região;

- o que o município é capaz de fazer em termos de competência e capacidade de atendimento ao turista;

- o que o município quer fazer, considerando os interesses do turista, do comércio e do setor de serviços e

- o que o município deve fazer considerando as restrições sociais, éticas e culturais.

Isto mostra que o planejamento turístico deve abranger todas as áreas de interesse do município, tanto nas questões econômicas quanto sociais, culturais e ambientais, para que este se desenvolva de maneira a minimizar os impactos negativos causados ao local e à população. 
A comunidade precisa estar preparada para lidar com as transformações que o turismo possa trazer, garantindo a sobrevivência da atividade turística. Para tal, o treinamento da população deve fazer parte do planejamento turístico, não somente para preparar a mão de obra, como mostrando a todos quais os cuidados que devem ser observados para garantir a continuidade da atividade turística na região.

Por ser um campo de estudo novo, principalmente no que tange a plano de desenvolvimento turístico, as limitações relacionadas à abrangência e profundidade de estudos científicos dificultam o acesso aos dados que se fazem necessários para o aprofundamento da pesquisa. A escassez de literatura,no Brasil, relacionada ao desenvolvimento turístico não invalida este estudo que se propôs a contribuir para com um conjunto de informações importantes para o campo de turismo, bem como orientar os municípios na elaboração do plano de desenvolvimento da sua localidade com diversas visões.

Foram estudados os seguintes autores por proporem metodologias para planos de desenvolvimento do turismo, dando diferentes enfoques ao planejamento: Bissoli (2002), com sua visão municipal; Petrocchi (1998), que tem uma visão sistêmica e Ruschmann (1997) abrange, a mais nova visão em turismo, a sustentável.

Os planos de desenvolvimento apresentados estão vinculados ao Programa de Desenvolvimento de Turismo (PRODETUR), cujos responsáveis são as Secretarias de Turismo dos Estados que foram apresentados como projeto do Governo Federal para o turismo no Brasil. O problema básico de qualquer projeto governamental é a descontinuidade, que ocorre com a mudança de governo a cada quatro anos. É imprescindível a continuidade dos planos Independente do governo, uma vez que colocam em risco a sustentabilidade turística das localidades. 
Para futuros trabalhos de pesquisa, estudos relacionados aos seguintes temas poderão contribuir para o desenvolvimento da área de turismo nas ciências sociais e humanas:

- Analisar e estudar mecanismos práticos para coleta dos dados e informações das atividades municipais

- Analisar os banco de dados existentes que dão suporte às gestões públicas.

- Propor ações aos órgãos competentes para incentivo a área de turismo. 


\section{REFERÊNCIAS BIBLIOGRÁFICAS}

ANJOS, Francisco Antonio dos. Processo de planejamento e gestão de territórios turísticos: uma proposta sistêmica. Florianópolis, SC: UFSC, 2004. Originalmente apresentada como tese de doutorado. Universidade Federal de Santa Catarina UFSC, 2004.

ANTUNES, Rogéria. Desenvolvimento turístico: um olhar sobre as comunidades receptoras. In: RUSCHMANN, Doris Van de Meene e SOLHA, Karina Toledo (org.) Planejamento Turístico. Barueri, SP: Manole, 2006.

BAHL, Miguel. Planejamento turístico por meio da elaboração de roteiros. In: RUSCHMANN, Doris Van de Meene e SOLHA, Karina Toledo (org.) Planejamento Turístico. Barueri, SP: Manole, 2006.

BENI, Mario C. Sistema de Turismo: construção de um modelo teórico referencial para aplicação na pesquisa em turismo. São Paulo: Editora SENAC, 1998.

Análise estrutural do turismo. São Paulo: Editora SENAC, 1998.

ALEXANDRE, Lillian Maria de Mesquita. Política de Turismo e desenvolvimento local: um binômio necessário. In: BEZERRA, Deise Maria Fernandes (org.) Planejamento e gestão em Turismo. São Paulo: Roca, 2003.

BISSOLI, Maria A. M. Planejamento turístico municipal com suporte em sistemas de informação. São Paulo: Futura, 1999.

DENCKER, Ada de Freitas Maneti. Métodos e técnicas de pesquisa em turismo. São Paulo: Futura, 1998.

EMBRATUR/OMT. Desenvolvimento de Turismo Sustentável: manual para organizadores locais. Brasília, OMT e Ministério da Indústria, do Comércio e do Turismo, 1995.

FUNDAÇÃO JOÃO PINHEIRO. Centro de Estudos Econômicos e Sociais. Plano de Desenvolvimento Integrado do Turismo Sustentável do Pólo Turístico do Vale do Jequitinhonha. Belo Horizonte, 2004. 13 v. il.

LAKATOS, Eva Maria e MARCONI, Marina de Andrade. Fundamentos de metodologia científica. 4 ed. rev. e ampl. São Paulo: Atlas, 2001. 
. Desenvolvimento de Turismo Sustentável: Manual para Organizadores Locais. Publicação de Turismo e Ambiente. 2ª ed. Brasília, DF: Bárbara Bela, 2001.

MINTZBERG, Henry; AHLSTRAND, Bruce; LAMPEL, Joseph. Safari de Estratégia: um roteiro pela selva do planejamento estratégico. Trad. Nivaldo Montingelli Jr. Porto Alegre: Bookman, 2000. 299 p.

NICÁCIO, Jose Ângelo. Elementos necessários para o planejamento da sustentabilidade dos municípios de médio e pequeno porte. Florianópolis, SC: UFSC, 2002. Originalmente apresentada como tese de doutorado. Universidade Federal de Santa Catarina - UFSC, 2002.

OLIVEIRA, Antonio Pereira. Turismo e desenvolvimento: planejamento e organização. 4. ed. rev. e ampl. São Paulo: Atlas, 2002.

OLIVEIRA, Djalma de Pinho Rebouças de. Planejamento estratégico: conceitos, metodologia e práticas. 20ª ed. São Paulo: Atlas, 2004. 335p.

OMT - Organização Mundial de Turismo. Guia de desenvolvimento do Turismo sustentável. Trad. Sandra Netz. Porto Alegre: Bookman, 2003.

PETROCCHI, Mario. Gestão de Pólos Turísticos. São Paulo: Futura, 2001.

REJOWSKI, Mirian. Turismo e pesquisa científica: pensamento internacional $X$ situação brasileira. Campinas, SP: Papirus, 1996. (Coleção Turismo).

RIO GRANDE DO SUL (Estado). Secretaria da Coordenação e Planejamento e Secretaria de Turismo, Esporte e Lazer. PRODETUR SUL/RS. Plano de Desenvolvimento Integrado do Turismo Sustentável: Área prioritária Serra Gaúcha.Porto Alegre: Governo do Estado do Rio Grande do Sul, 2005. 252 p.

RODRIGUES, Diana Rita Ramos de Almeida. Desenvolvimento sustentável em turismo: percurso do Alva. Aveiro, Portugal: UA, 2004. Originalmente apresentada como dissertação de mestrado. Universidade de Aveiro, 2004.

RUSCHMANN, Doris Van de Meene. Turismo e planejamento sustentável: a proteção do meio ambiente. Campinas-SP: Papirus, 1997. (Coleção Turismo)

SCHULUTER, Regina G.. Metodologia da pesquisa em turismo e hotelaria. tradução Tereza Jardini. São Paulo: Aleph, 2003. (Série Turismo).

SILVEIRA JÚNIOR, Aldery; VIVACQUA, Guilherme. Planejamento Estratégico como instrumento de mudança organizacional. $2^{\underline{a}}$ ed. São Paulo: Atlas, 1999. 150 p.

THEOBALD, William F. (org.). Turismo Global. Tradução Anna Maria Capovilla, Maria Cristina Guimarães Cupertino, João Ricardo Barros Penteado. São Paulo: SENAC São Paulo, 2001.

TRIGO, Luiz Gonzaga G. Turismo básico. 6ª ed. rev. e ampl. São Paulo: Editora SENAC São Paulo, 2002. 